\title{
Analyzing the Determinants of Financial Distress in Indonesian Mining Companies
}

\author{
Submitted 23/07/19, 1st revision 12/09/19, 2nd revision 17/10/19, accepted 20/11/19
}

\author{
Muhammad Khafid $^{1}$, Tusyanah Tusyanah ${ }^{2}$, Tejo Suryanto ${ }^{3}$
}

\begin{abstract}
:
Purpose: The objective of the study is to analyze the effect of leverage, liquidity and managerial ownership on financial distress at mining companies in Indonesia. The study also examines the moderating role of profitability on the effects of leverage, liquidity and managerial ownership on financial distress.

Design/Methodology/Approach: The population of this study is 41 mining sector companies listed in Indonesian Stock Exchange in 2013-2015. There are 17 companies as the sample of the study taken by purposive sampling method; then there are 51 units of analysis which are suitable to the predetermined criteria. Data are analyzed by descriptive statistical analysis and logistic regression for inferential conclusions.

Findings: The results of the study show that the leverage has a positive effect on financial distress. Then, liquidity and managerial ownership do not have any effect on financial distress. Furthermore, profitability as the moderating variable is not proven to moderate the effect of leverage and managerial ownership on financial distress. However, profitability is proven to moderate significantly the effect of liquidity on financial distress.

Practical Implications: This study has the guidance and or feedback to the company management to avoid financial distress.

Originality/Value: The research places profitability as the moderating variable to analyze the simultaneous effect among leverage, liquidity, managerial ownership with profitability on financial distress. Then, it takes the mining sector companies as the sample to be analysed.
\end{abstract}

Keywords: Leverage, liquidity, managerial ownership, financial distress, profitability.

JEL codes: O40, C23, O52.

Paper type : Research article.

\footnotetext{
${ }^{1}$ Associate Professor, Universitas Negeri Semarang, email: muh-khafid@mail.unnes.ac.id

${ }^{2}$ Lecturer, Universitas Negeri Semarang,email: tusyanah@mail.unnes.ac.id

${ }^{3}$ Universitas Negeri Semarang; email: tejosuryanto@gmail.com
} 


\section{Introduction}

Financial distress is a situation where a company fails or is unable to fulfill its obligations to the debtor because the company experiences deficiency and insufficient funds in which the total liabilities outweigh the total assets, and it cannot achieve the company's economic goal or profit. Baza and Rao (2017) says that financial distress is a term in corporate finance used to show a condition when the company's promises to creditors are broken or honored with difficulty. If financial distress cannot be handled well, it leads to bankruptcy. Financial distress is a broad concept consisting of several situations in which companies face financial difficulty. The most common terms used to describe these situations are 'bankruptcy', 'failure', 'insolvency', and 'default'. Chiaramonte and Casu (2017) state that bankruptcy is close related to the legal definition of financial distress. Then Zmijewski (1984) defines financial distress as the act of filing a petition for bankruptcy.

However, many financial-distressed companies were not entitled as at the bankruptcy situation, due to acquisition or privatization. On the other hand the good companies sometimes were entitled as the bankrupted companies to avoid taxes and expensive lawsuits (Theodossiou et al., 1996). Failure of a company is a circumstance where a company could not pay lenders, preferred stock shareholders, suppliers, etc., or a bill is overdrawn. All these situations resulted in a discontinuity of the company's operations (Dimitras et al., 1996).

It is common to see companies struggling to turn around from their financial distress. Each company expects to run the business well. In other words, the company does not want the financial distress since it eventually leads to the bankruptcy. The company wants its business to have maximum results with good financial statements every year. Profit is one of the business goals; it makes the company survive in the business world in the long term as stated at its vision and mission.

There are many researchers who are interested to do researches on financial performance and the research results are various. For example Shahwan (2015) examines the effect of Corporate Governance (CG) on financial performance. He finds that the results do not support the positive relationship between CG practices and financial performance or there is an insignificant negative relationship between $\mathrm{CG}$ practices and financial distress.

Achim et al. (2010) also mentioned that on the occasion of economic and/or financial crisis, among their causes there are mentioned causes related to managers' irresponsible actions, managers who, together with accounting professionals, chose to alter accounting data in order to create a more appealing image on the market of the company's financial status and Geng, Bose and Chen (2015) do study the prediction of financial distress. This paper studies the phenomenon of financial distress for 107 Chinese companies which receive the label 'special treatment' from 2001 to 2008 by the Shanghai Stock Exchange and the Shenzhen Stock Exchange. An important 
contribution of the paper is to discover that financial indicators, such as net profit margin of total assets, return on total assets, earnings per share, and cash flow per share. They all play the important role in predicting the deterioration of profitability.

From various studies the results are interesting to be examined because not all expectations of a company can be achieved. Along with the development of the global era, some problems came out on a significant matter. There are many obstacles faced by a company running its business, for example, the weakening current value of Indonesian Rupiah against the American Dollar. It will hinder the company in its operation. Many companies are experiencing a decrease in profits or losses or what we usually call it financial distress. For example the stock from sahamok.com (2015), PT. Delta Dunia Makmur Tbk experienced losses many times. It has a value of IDR $352,477,000$ in 2009, then, it went down to IDR 158,736,000 in 2010 and IDR $168,106,000$ in 2011. Then, PT Aneka Tambang (Persero) Tbk (ARII) also experienced losses from IDR 2,065,884,091,526 in 2013 to IDR 720,080,469,181 in 2014 to IDR $965,672,947,183$ in 2015 and in 2016, it went down to IDR $786,158,903,636$.

Furthermore, it was launched by kaltim.tribunnews.com (2015) that global economic crisis increasingly went acute. The mining and plantation companies got the worst impact. There were 125 coal mining companies in East Kalimantan closed their operations or they were bankrupt. It happened because the companies were not able to generate maximum profit and it is worsen by the higher burden companies therefore the companies might experience financial distress and it was getting worse into bankruptcy. Therefore, the company should be able to detect factors of financial distress before going to bankruptcy. There are many factors which indicate that the company will experience financial distress such as liquidity, profitability, leverage, institutional ownership, and ownership managerial.

There are three (3) factors used in this research. First, leverage measured by the leverage ratio/ROA; it is total debt divided by total assets. Second, liquidity, it is measured by liquidity ratio. Third, managerial ownership, it is measured by the shares owned by management per shares in circulation.

There are many researches on leverage, liquidity and managerial ownership and financial distress. Andualem (2015) states that there is a positive and significant relationship between insider's ownership and likelihood of financial distress. Then, the result of the study also proves that liquidity, profitability and efficiency have positive and significant effect on debt service coverage. On the contrary, leverage has negative and significant effect on debt service coverage.

Furthermore, a research on financial performance is also conducted by state-owned status helps companies in decreasing their DOFD and that the separation of cash-flow rights and control rights is positively related to the DOFD. 
It can be seen that the results of the previous research are inconsistent research results. Therefore the study adds profitability as the moderating variable. Profitability is used as the moderating variable because the previous studies always show the strong effect on the negative direction on financial distress. Profitability is expected to moderate the relationship among leverage, liquidity, and managerial ownership on financial distress. The purpose of this study is to analyze the factors predicting the condition of the financial distress as stated above using only three factors among many others.

\section{Financial Distress Determinants}

Kaplan and Norton (2005) measure performance into 4 aspects of assessment, namely starting from learning and growth, internal business processes, customer aspects and financial aspects. These four aspects are known as the Balanced Scorecard. BSC accommodates a complete picture of organizational performance through 4 perspectives: financial goals, customer perspective, internal processes, and learning and innovation.

The research uses agency theory and pecking order theory. Jensen and Meckling (1976) describe the agency relationship as a contract under one or more principals involving agents to perform some services for them by delegating decision-making powers to agents. Principals and agents are two or more persons who work together for the management of the company, they have their own motivation to carry out their respective duties. The principal or owner or shareholder gives instructions to the agent to manage the company to achieve the company's glory. On the other hand, some management agents might perform inappropriately to the instructions ordered by the principal. Agents are more concerned on achieving the better results than always obeying to the principal's instructions.

Then, the second theory used in the study is Pecking Order Theory. The theory says that the decline in the value of a company is caused by the high ratio of this debt (Weston and Copeland, 1992 in Eliu, 2014). The higher the debt ratio the greater risk which leads to potential bankruptcy. Hussan (2016) does a research on the impact of leverage on risk of the companies. He says that leverage ratios include the debt-toassets ratio and debt-to-equity ratio. Higher leverage ratio, higher debt level. All creditors and debt holders have first claim to a company's assets in the event of failure. If a company with high debt level fails, its shareholders may not receive anything. So it can be concluded that leverage positively influence the financial distress which is suitable to the Pecking Order Theory.

\subsection{Leverage and Financial Distress}

The next variable is the liquidity. It occupies a central importance in many areas of finance (Ohara, 2004). Cash, savings account, checkable account are liquid assets because they can be easily converted into cash. The company can be said liquid if the company has the liquid assets which can be used to fulfill all its financial obligations. 
Based on agency theory, disclosure of liquidity ratio is one form of the company's responsibility as an agent to the shareholders (principal). This theory states that there is agreement between both parties, shareholders and management. Then, Chiaramonte and Casu (2017) do study capital and liquidity ratios and financial distress. Evidence from the European banking industry found that capital and liquidity ratio play a complementary role in ensuring bank soundness, but only for the largest banking groups.

\subsection{Liquidity and Financial Distress}

The next variable is managerial ownership. Managerial ownership is the amount of share owned by the management or the directors of the company (Khafid, 2012). The agency theory clearly determines this relationship. The higher managerial ownership, the more information owned by the company to anticipate the occurrence of financial distress. Jensen and Meckling (1976) state that managers have a tendency to earn additional income from corporate resources for their own consumption. It shows that the management emphasizes more on profit and the owner expects that the manager is able to manage the company well and earns the high profit.

The previous research results above show that managerial ownership influences the financial performance of the company. Managerial ownership of the company is expected to decrease the agency conflicts because management ownership shows that the company is owned by the management of the company itself. Li, Wang and Deng (2008) say that ownership concentration, state ownership, ultimate owner, independent directors and auditors' opinion turn out to be negatively associated with the probability of financial distress. Md-Rus et al. (2013) find the relationship between ownership structure and financial distress. One structure ownership variable is managerial ownership. The result of the study shows that managerial ownership has negative effect on financial distress. It shows that managerial ownership as an alternative to avoid financial distress is proven.

\subsection{Managerial Ownership and Financial Distress}

The next variable is leverage. Leverage is the portion of the fixed costs which represents risk to the company. The leverage ratio emphasized how much the debt proportion is used in the funding of a company's assets. Moreover, in the agency theory, the company's survival is in the agents' hands. Leverage ratio is known to play a significant implication in financial condition companies. A study on leverage done by Baza and Rao (2017). The result of the study shows the leverage has negative and significant influence on financial distress.

In the previous study, the effect of leverage on financial distress is inconsistent. So, we added profitability variable to moderate. Profitability is chosen because every profit earned by the company from its production activities will increase the company's assets and could be used to pay corporate liabilities. It is expected that 
profitability is able to moderate leverage relationship on financial distress. It is suitable to Pecking Order Theory.

Profitability is the result of interaction of controllable and uncontrollable factors. The uncontrollable factors are the economic and political environment, market growth or decline, inflation, etc. These uncontrollable factors could impose significant positive or negative impact on profitability (Loggerenberg and Cucchiaro, 1981). Salehi, Moradi and Paiydarmanesh (2017) find that there is a positive and significant relationship between corporate debt level and managerial ownership in the Iranian listed companies. The authors also find no convincing evidence that either the company's growth or financial health could influence or moderate this interrelationship.

\subsection{Leverage Influences Financial Distress Moderated by Profitability}

The next variable is liquidity. Liquidity is in its broadest sense defined by the Committee of European banking supervisors as a capacity to obtain funding (Cernohorsky, Teply and Vrabel, 2010). According to the agency theory, the company's receivable debt decision is under the control of the agent. Therefore, the existence of current financial liabilities is due to the decision of an agent to engage loans or credit to outsiders in the past time. If a company has a total of overdue obligations, it is necessary to investigate whether there is a mistake on the agent in managing the company or not, because if the situation is not quickly handled it will bring the company closer to the financial distress (Khafid, 2012).

Profitability as the moderating variable is supported by previous research on the effect of liquidity on financial distress which resulted in fluctuated situation. It is appropriate with agency theory's statement that profitability is one form of responsibility of the agent to the shareholders in handling the company. The higher the profitability the more trustworthy the shareholders on the agent or management. Companies which had high profitability will make the company's current assets increased. It influenced the company's ability to fulfill the current obligations which will increase as well which finally could avoid financial distress.

\subsection{Liquidity Influences Financial Distress Moderated by Profitability}

It has been previously investigated that managerial ownership is assumed to reduce agency problems arising in a company. If directors have shared ownership in the corporation the shareholders' interest will be more effectively monitored and fulfilled (Li et al., 2008). However, many previous researches on managerial ownership and financial distress are still inconsistent; therefore, the researchers are interested to present profitability as the moderating variable. If it is high profitability, it is likely that management will invest more at its own company. With the large amount of managerial ownership, it will improve management performance in developing its 
business. A large proportion of managerial ownership will also provide a sense of security for the outside investors to trust management.

\subsection{Managerial Ownership Influences Financial Distress Moderated by Profitability}

Based on the above description, the theoretical framework of the study is presented in Figure 1.

Figure 1. The Research Framework

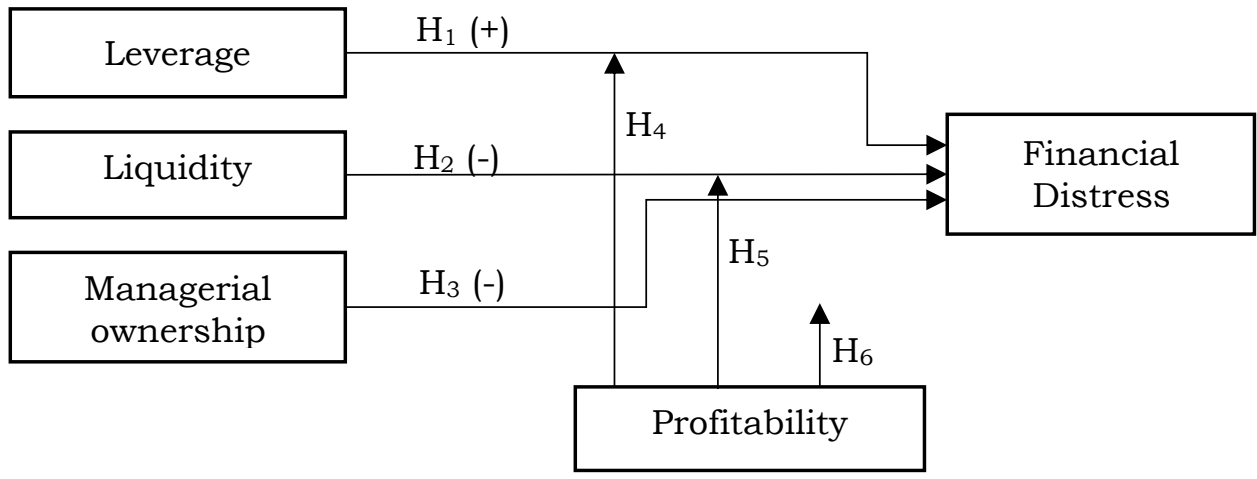

\section{Theoretical Foundation and Research Focus}

\subsection{Methodological Issues}

It is a quantitative research and it uses secondary data. The population of the study is mining companies listed at Indonesian Stock Exchange from 2013 up to 2015. The taken samples are suitable to certain predetermined criteria. The samples taken by purposive sampling method, there are 41 companies as the population and 17 companies as the samples with the observation duration for 3 years from 2013 to 2015. The summary of the research sample selection process can be seen in Table 1.

The dependent variable of this study is financial distress. The independent variables of this study are leverage, liquidity, and managerial ownership. The moderating variable is profitability. The operational definitions of variables and measurement indicators can be seen in Table 2:

Data are collected by using documentation technique on financial reports and annual reports of mining companies listed in the Indonesian Stock Exchange from 2013 up to 2015. Then, data are analyzed by descriptive statistical analysis and logistic regression analysis. Descriptive statistics are used to find out the minimum, maximum, mean, and standard deviation. Logistic regression analysis is used to test the effect of independent variables on the dependent variable. They, in overall, fit well 
based on the Goodness-of-fit test, Nagelkerke's R square, multicolonierity test, classification matrix, and hypothesis test results. Then, the absolute value difference model is used to test the moderating variable.

Table 1. The Sample Selection Process based on the Criteria

\begin{tabular}{llll}
\hline No. & Criteria & $\begin{array}{l}\text { Unlisted } \\
\text { Criteria }\end{array}$ & $\begin{array}{c}\text { Total } \\
\text { number }\end{array}$ \\
\hline 1 & $\begin{array}{l}\text { The mining companies listed on Indonesian Stock } \\
\text { Exchange in the period of 2013-2015 } \\
2\end{array}$ & $\begin{array}{l}\text { The mining companies publishing the financial } \\
\text { reports respectively in the period of 2013-2015 }\end{array}$ & 31 \\
3 & $\begin{array}{l}\text { The mining companies having the managerial } \\
\text { ownership in the period of 2013-2015 }\end{array}$ & 30 \\
$\begin{array}{l}\text { The final sample total } \\
\text { Years of observation }\end{array}$ & 17 \\
& The Numbers of Observation & 17 \\
\hline
\end{tabular}

Source: idx.co.id in 2017.

Table 2. The Definitions of Operational Variables

\begin{tabular}{|c|c|c|c|}
\hline No. & Variables & The Operational Definitions & Indicators/ Measurement \\
\hline 1. & $\begin{array}{l}\text { Financial } \\
\text { Distress }\end{array}$ & $\begin{array}{l}\text { Financial distress is a } \\
\text { situation where a } \\
\text { company's operating cash } \\
\text { flows are not sufficient to } \\
\text { satisfy current obligation } \\
\text { (Ross, Westerfield, and } \\
\text { Jaffe, 2002) }\end{array}$ & $\begin{array}{l}\text { ICR = EBIT/ Interest expense } \\
\text { (Sengani and Gomathi, 2014) } \\
\text { ICR is under } 1 \text {; experiencing } \\
\text { financial distress; } \\
\text { ICR is more than } 1.5 \text {; it does } \\
\text { not experience financial } \\
\text { distress }\end{array}$ \\
\hline 2. & Leverage & $\begin{array}{l}\text { Leverage is a ratio used to } \\
\text { measure the extent to which } \\
\text { the company's assets are } \\
\text { financed by debt } \\
\text { (Kasmir, 2014) }\end{array}$ & $\begin{array}{l}\text { Total Liabilities / Total Assets } \\
\text { (Kasmir, 2014) }\end{array}$ \\
\hline 3. & Liquidity & $\begin{array}{l}\text { Liquidity shows the } \\
\text { company's ability to meet } \\
\text { its short-term obligations } \\
\text { (Kasmir, 2014) }\end{array}$ & $\begin{array}{l}\text { Current Assets / Current } \\
\text { Liabilities (Kasmir, 2014) }\end{array}$ \\
\hline 4. & $\begin{array}{l}\text { Managerial } \\
\text { ownership }\end{array}$ & $\begin{array}{l}\text { Managerial ownership is the } \\
\text { amount of share ownership } \\
\text { by the management and the } \\
\text { director of the company } \\
\text { (Khafid, 2012) }\end{array}$ & $\begin{array}{l}\text { Number of shares owned by } \\
\text { management or director / total } \\
\text { shares outstanding } \\
\text { (Khafid, 2012) }\end{array}$ \\
\hline 5. & Profitability & $\begin{array}{l}\text { Profitability is the ability to } \\
\text { earn a profit (Hartoyo et al, } \\
\text { 2014) }\end{array}$ & $\begin{array}{l}\text { Net Income / Total Assets } \\
\text { (Kasmir, 2014) }\end{array}$ \\
\hline
\end{tabular}




\section{Results}

The proposed model has one binary-dummy variable, the financial distress variable. The frequency distribution is presented in Table 3.

Table 3. Number of Companies on Financial Distress and Non-Financial Distress Categories

\begin{tabular}{llllll}
\hline \multirow{2}{*}{ Categories } & \multicolumn{3}{l}{ Year } & \multicolumn{3}{c}{ Total } \\
\cline { 2 - 5 } & 2013 & 2014 & 2015 & \\
\hline Financial distress & 5 & 4 & 8 & 17 \\
Non financial distress & 12 & 13 & 9 & 34 \\
Total & 17 & 17 & 17 & 51 \\
\hline
\end{tabular}

Source: idx.co.id

Based on Table 3, it can be seen that there are 17 data companies experiencing financial distress. The details are 5 companies experiencing financial distress in 2013, 4 companies in 2014 and 8 companies in 2015. On the other hand leverage, liquidity, ownership and profitability are variables for which the minimum, maximum, mean, and standard deviation can be determined. The descriptive statistics are in Table 4.

Table 4. The Descriptive Statistic Analysis on Leverage, Liquidity, Managerial Ownership and Profitability

\begin{tabular}{llllll}
\hline & $\mathrm{N}$ & Minimum & Maximum & Mean & Std. Deviation \\
\hline Leverage & 51 & 0.09779 & 1.11793 & 0.4689010 & 0.22399009 \\
Liquidity & 51 & 0.20500 & 3.90613 & 1.8666492 & 0.95008895 \\
Managerial Ownership & 51 & 0.00000 & 0.66460 & 0.1148894 & 0.21064070 \\
Profitability & 51 & -0.72133 & 0.16555 & 0.0070116 & 0.13880568 \\
Valid N (listwise) & 51 & & & & \\
\hline Source: & & & & & \\
\hline
\end{tabular}

Source: idx.co.id.

\subsection{Inferential Statistical Analysis}

The results show that -2LL step 1 decreases by 41.678. It is the difference between 2LL step 0 for 64.924 and -2LL step 1 for 23.246. This decrease shows a good regression model or the hypothesized model fits to the data. The value of Chi-Square is significant. Therefore, the regression model could be used to predict financial distress. The value of Chi-Square is 8.137 with its significance level being 0.420 . The significant value is greater than 0.05 therefore the hypothesis is accepted; this means that there is not any difference between the model and the data. The results show that the regression model is feasible to be used in subsequent analysis because its corresponds to the data. Based on the results, the value of Nagelkerke R Square is 0.765 ; it means that the dependent variable is explained quite well by the independent variables. 
Based on the results from 51 samples of observation data, the regression model is relevant to predict the probability of companies experiencing financial distress by $76.5 \%$. It means that 13 companies are likely to experience financial distress from 17 companies. On the other hand, the strength of the regression model to predict the probability of companies which does not experience financial distress is $97.1 \%$. It means that 33 companies out from 34 do not experience financial distress. Furthermore, the prediction ability of the model with leverage, liquidity and managerial ownership variables can statistically predict up to $90.2 \%$.

The result of multicollinearity test shows that there are not any symptoms of multicollinearity among independent variables. There is not any presence of a correlation value exceeding 0.90 . Based on those results, it means that there is not any multicollinearity symptom for the regression used for independent variables of leverage, liquidity, managerial ownership and profitability (the moderating variable).

To test the hypothesis we use a logistic regression test conducted on all variables, leverage, liquidity, managerial ownership and profitability on financial difficulties. Hypothesis test results in logistic regression output can be seen for the independent variables in the equations presented in the following Table 5:

Table 5. Regression Coefficient Test

\begin{tabular}{clllllll}
\hline \multicolumn{1}{c}{ B } & S.E. & Wald & df & Sig. & $\operatorname{Exp(B)}$ \\
\hline \multirow{6}{*}{ Step 1a } & & & & & & \\
& LEV & 8.524 & 4.343 & 3.852 & 1 & .050 & 5035.559 \\
& LIK & 1.093 & 1.006 & 1.180 & 1 & .277 & 2.984 \\
& KM & 3.699 & 6.591 & .315 & 1 & .575 & 40.391 \\
& RPRO & -.123 & .097 & 1.601 & 1 & .206 & .884 \\
& MOD1 & -.224 & .127 & 3.080 & 1 & .079 & .800 \\
& MOD2 & -.244 & .123 & 3.901 & 1 & .048 & .784 \\
& MOD3 & -.240 & .136 & 3.112 & 1 & .078 & .787 \\
& Constant & .956 & 2.716 & .124 & 1 & .725 & 2.601 \\
\hline
\end{tabular}

Source: The Processed Data with IBM SPSS 21.0 (2017).

Table 6 presents the summary of the research results:

Table 6. The Summary of the Research Results

\begin{tabular}{|c|c|c|c|c|}
\hline \multicolumn{2}{|c|}{ Hypothesis } & $\begin{array}{l}\text { The Values of } \\
\text { Regression } \\
\text { Coefficient (B) }\end{array}$ & $\begin{array}{l}\text { The Results } \\
(\alpha=0,05)\end{array}$ & Notes \\
\hline H1 & $\begin{array}{l}\text { Leverage has the positive } \\
\text { effect on Financial } \\
\text { Distress }\end{array}$ & 8.524 & $0.050=0.05$ & Accepted \\
\hline $\mathrm{H} 2$ & $\begin{array}{l}\text { Liquidity has the negative } \\
\text { effect on Financial Distress }\end{array}$ & 1.093 & $0.277>0.05$ & Rejected \\
\hline
\end{tabular}




\begin{tabular}{lllll} 
H3 & $\begin{array}{l}\text { Managerial ownership has } \\
\text { the negative effect on }\end{array}$ & 3.699 & $0.575>0.05$ & Rejected \\
H4 & $\begin{array}{l}\text { Financial Distress } \\
\text { Leverage influences } \\
\text { Financial Distress } \\
\text { moderated by profitability }\end{array}$ & -0.224 & $0.079>0.05$ & Rejected \\
H5 & $\begin{array}{l}\text { Liquidity influences } \\
\text { Financial Distress } \\
\text { moderated by profitability }\end{array}$ & -0.224 & $0.048<0.05$ & Accepted \\
H6 & $\begin{array}{l}\text { Managerial ownership } \\
\text { influences Financial } \\
\text { Distress moderated by } \\
\text { profitability }\end{array}$ & -0.240 & $0.078>0.05$ & Rejected \\
\hline
\end{tabular}

Source: The processed data with IBM SPSS 21.0 (2017).

\subsection{Leverage Has Positive Effect on Financial Distress}

The results show that leverage has positive effect on financial distress, therefore $\mathrm{H} 1$ is accepted. Based on the result above, the high or low debt levels that could predict the companies are in financial distress or not. Companies experiencing financial distress generally had almost equal amounts between debt and total assets and even few companies had higher debt amounts than total assets which generally have the negative equity. Therefore the high leverage allowed companies have greater financial distress opportunities.

It is appropriate to pecking order theory. It is said that the value decline of a company is caused by the high ratio of debt (leverage) (Weston and Copeland, 1992 in Eliu, 2014). The higher the debt ratio led to greater risk and could lead to bankruptcy. Therefore, companies experiencing financial distress should be seen from the leverage level. According to Thim, Choong and Nee (2011) low profitability can make the company experiencing the first few symptoms of financial distress such as the decline in current assets, the delay in repayment of liabilities and other asset used as the operating capital.

It is also possible for the companies having the high debt to violate the debt agreement with the creditor because the amount of owned assets does not guarantee the debts. The companies which have high debt will also be charged with high interest costs. The high debt of the company's total assets makes the company's equity book value negative.

\subsection{Liquidity Has the Negative Effect on Financial Distress}

The research shows that the liquidity variable measured by current ratio do not have any effect on financial distress, therefore $\mathrm{H} 2$ is rejected. The high liquidity cannot protect the company from financial distress or vice versa. Companies with a high current ratio are usually due to their current assets which are not needed and therefore 
they do not provide income, the amount of funds which are heavily embedded in the form of accounts receivable might prove uncollectible. The impact of uncollectible accounts makes the company unable to pay its liabilities in the short term by using its current assets; therefore, it influences the company's potential to experience financial distress.

Agency theory does not support the effect of liquidity toward financial distress. Based on agency theory, disclosure of liquidity ratio is one form of responsibility of a company as an agent to shareholders (principal). This theory states that there is an agreement between both parties shareholders and management. It is expected to maximize the utility of the owner (principal), and can satisfy and guarantee the management (agent) to receive rewards. The benefits received by both parties are based on the company's performance.

It is similar to the research conducted by Chiaramonte and Casu (2017) that liquidity does not have any significant influence in predicting the condition of financial distress because there is not any significant difference between the liquidity of companies experiencing financial distress and companies which do not experience financial distress. It will further ensure that the company can pay its current liabilities on time and the potential of financial distress will be smaller.

\subsection{Managerial Ownership Has Negative Effect on Financial Distress}

The results shows that managerial ownership variable does not have any effect on financial distress, therefore $\mathrm{H} 3$ is rejected. It shows that the high level of managerial ownership cannot predict if the company is experiencing financial distress or not. The managerial ownership data in mining companies has almost the same value every year. This makes financial distress unpredictable. Furthermore, managerial ownership is only a symbol which is used to attract the investors' attention. If the investor knows that a company's shares are also owned by its management, then the investor will assume that the value of the company will also increase.

Jensen and Meckling (1976) argue that managers have a tendency to earn additional income from corporate resources for their own consumption. It shows that the management gives more emphasis on profit only. While the owner expects that the manager is able to manage the company well and earns a high profit. Therefore, the study does not support agency theory, which clearly states that the higher the managerial ownership of a manager, the more information owned in the company to anticipate the occurrence of financial distress. Li et al. (2008) studied the relationships between the ownership structure attributes and the risk of financial distress for publiclisted companies in China. The results show that ownership concentration and state ownership are negatively associated with the probability of financial distressed. It suggests that large shareholders and the state share owners have incentives to hold back financial distress. 


\subsection{Profitability Moderates the Effect of Leverage on Financial Distress}

The result shows that profitability is not able to moderate the effect of leverage on financial distress or $\mathrm{H} 4$ is rejected. It shows that the company's low profit does not guarantee the rise or the fall of the company's debt. Therefore, the factor is not able to predict the financial distress condition or not. The level of debt (leverage) will not necessarily decrease along with high profitability. Due to high profitability, it will increase the production costs. Production cost is not always from its own capital. Therefore, the company implemented the debt policy to support high profits which consequently increased the company's debt. It will indirectly influence the company's financial distress. In other words, high profit is not always related to the low debt ratio; therefore, leverage cannot predict the condition of financial distress.

Hussan (2016) does a study on the impact of leverage on company risks. He finds that leverage can be defined as a long term debt to improve the financial performance as well as to gain the success of the organization. It means that the borrowed funds can establish investment and return on that investment but it is more risky if they cannot be able to generate higher rate of return comparing with the cost of capital. Thus, the determination of the proportion of debt and equity is one of the most basic decisions because leverage can influence a company's financial capacity, risk, return, investment, strategic decision and the wealth of an organization.

The results of this study do not support agency theory which says that the main purpose of the company is to increase the value of the company by increasing the owners's or shareholder's wealth (Brigham and Houston, 2012). Prosperity of the owner could be seen from the profit of the company; the higher the profit, the more prosperous the owner will be. Agents used debt policy to increase profit. This will lead to agency conflict since it drives the company in financial distress.

According to Baza and Rao (2017) the highly leveraged companies have high debt to equity ratio or high debt to total asset ratio. High leverage leads companies to bankruptcy, or bankruptcy leads for liquidation or restructuring or reorganization. However, high leverage value does not guarantee that the company got financial distress. It is possible that high leverage value is not the same to higher load, the company could generate high profits and does not lead to financial distress.

Khafid (2012) said that the greater the leverage ratio, the higher the company's debt value. It happens if the debt proportion is higher than the asset proportion. However, the profit is seen from the value of profitability. Therefore, high leverage could also be followed by high profitability, therefore it cannot predict the financial distress.

\subsection{Profitability Moderates the Effect of Liquidity on Financial Distress}

The result of the research shows that profitability could moderate the effect of liquidity to financial distress or H5 is accepted. It shows that the higher the company's profit, 
the easier for the company to pay short-term debt, so the factor is able to avoid financial distress or vice versa.

Liquidity is the company's ability to finance its short-term debt; on the other hand profitability is the ratio to calculate the company's earnings in a period. The higher profits will increase the company's current assets, in other words the short-term debt of the company will be fulfilled in line with the increase in current assets of the company. Therefore, the liquidity of the company will increase if the profitability of the company is high and finally, the company could avoid financial distress.

It is in accordance with the agency theory the company's debt receivable decision is under the control of the agent. Therefore, the existence of financial obligations due today is the result of an agent's decision in the past decided to engage in loans or credit to an external party. If a company has a total of overdue obligations, it is necessary to investigate whether there is a mistake on the agent in managing the company, because if the situation is not quickly handled well, it brings the company closer to the financial distress (Li et al., 2008). Then, the agent will try to increase the company's net profit to avoid financial distress.

\subsection{Profitability Moderates the Effect of Managerial Ownership on Financial Distress}

The results show that profitability is not able to moderate the effect of managerial ownership on financial distress or H6 is rejected. Management as the main actor in the company knew a lot about the conditions which are going on in the company. The high profitability value of the company does not necessarily show if the company is in good condition. The productivity of the company with high operational costs using the company's debt and productivity with fixed operating costs by raising the cost of goods sold, will also generate high profits. Management will not invest in its own company under this condition.

Therefore, the high value of profitability will not increase the interest of management in investing into its business. Managerial ownership in mining companies almost every year has the same value. Many mining companies do not have any managerial ownership proportion at all. It does not give any effect on financial condition despite high or low profit. Therefore, the financial distress could not be predicted. It does not support the agency theory because managerial ownership is assumed to reduce agency problems arising in a company (Khafid, 2012).

In accordance with the agency theory, profitability is one form of agent responsibility to the principal. The higher the profitability, the more trustworthy shareholders to management because it will increase the utility of the principal. However, the management or agent is not able to increase profitability even high managerial ownership level cannot reduce the potential for financial distress. 


\section{Conclusions and Policy Implications}

The results of this study show that leverage has a positive and significant effect on financial distress. Then, liquidity and managerial ownership do not have any effect on financial distress. Next, profitability is not able to moderate the effect of leverage and managerial ownership on financial distress. However; the profitability is able to moderate the effect of liquidity on financial distress.

Then, it is suggested for further research to replace other moderating variables which are able to strengthen or weaken the effect of independent variables on the dependent variable. Most mining companies have the same managerial ownership every year so it is possible for further research to observe other companies. Moreover the population used is only mining companies listed in the Indonesian Stock Exchange in the study period of 2013-2015. Therefore, the next researchers can extend the object of this study and its sample period.

\section{References:}

Achim, M.V., Borlea, N.S. and Breban, L. 2010. Financial Crisis and Accounting Information: The Need for Corporate Social Responsibility in Accounting Profession. European Research Studies Journal, Volume XIII, Issue 3, 39-62.

Andriyani, R., Khafid, M. 2014. Analisis Pengaruh Leverage, Ukuran Perusahaan dan Voluntary Disclosure Terhadap Manipulasi Aktivitas Riil. Accounting Analysis Journal, 3(1), 361-369. https://doi.org/ISSN 2252-6765.

Andualem. 2017. Financial Inclusion in Ethiopia. International Journal of Economics and Finance. https://doi.org/10.5539/ijef.v9n4p191.

Baza, A.U., Rao, K.S. 2017. Financial inclusion in Ethiopia. International Journal of Economics and Finance, 9(4), 191-201.

Brigham, E.F. and Houston, J.F. 2012. Fundamentals of financial management. Cengage Learning.

Černohorský, J., Teplý, P. and Vrábel, M. 2010. Liquidity market support during the global crisis. Scientific Papers of the University Pardubice, 17(2), 39-49.

Chiaramonte, L., Casu, B. 2017. Capital and liquidity ratios and financial distress. Evidence from the European banking industry. British Accounting Review, 49(2), 138-161. https://doi.org/10.1016/j.bar.2016.04.001.

Dimitras, A.I., Zanakis, S.H., Zopounidis, C. 1996. A survey of business failures with an emphasis on prediction methods and industrial applications. European Journal of Operational Research, 90(3), 487-513.

Eliu, V. 2014. Pengaruh Financial Leverage dan Company Growth Terhadap Financial Distress. Finesta, 2(2), 6-11.

Geng, R., Bose, I., Chen, X. 2015. Prediction of financial distress: An empirical study of listed Chinese companies using data mining. European Journal of Operational Research, 241(1), 236-247. https://doi.org/10.1016/j.ejor.2014.08.016.

Hartoyo, A.K.W., Khafid, M., Agustina, L. 2014. Faktor-Faktor yang Mempengaruhi Struktur Modal Perusahaan Tekstil dan Garmen di BEI. Accounting Analysis Journal, 3(2), 247-254.

Hussan, J. 2016. Impact of leverage on risk of the companies. Journal of Civil \& Legal Sciences, 5(4), 1-3. 
Jensen. 2010. Simultaneous Determination of Insider Ownership, Debt and Dividend Policies. In Jensen, G.R., Solberg, D.P., Zorn, T.S., published by the University of Washington, School of Business Administration.

Kaltim.Tribunnews.com. 2015. Gawat, 125 Perusahaan Tambang Batu Bara Bangkrut, 5.000 Korban PHK. Pukul 07.39.

Kasmir. 2014. Analisis Laporan Keuangan, Edisi Pertama, Cetakan Ketujuh. Jakarta: PT. Rajagrafindo Persada.

Kaplan, R.S. and Norton, D.P. 2005. The balanced scorecard: measures that drive performance. Harvard Business Review, 83(7), 172.

Khafid, M. 2012. Pengaruh tata kelola perusahaan (Coporate Governance) dan Struktur kepemilikan Terhadap Persistensi Laba. Jurnal Dinamika Akuntansi, 4(2), 139-148.

Khafid, M., Arief, S. 2017. Managerial ownership, corporate governance and earnings quality: the role of institutional ownership as moderating variable. Pertanika Journal of Social Science and Humanities, 25(3), 241-254.

Li, H.X., Wang, Z.J., Deng, X.L. 2008. Ownership, independent directors, agency costs and financial distress: Evidence from Chinese listed companies. Corporate Governance, 8(5), 622-636. https://doi.org/10.1108/14720700810913287.

Loggerenberg, B.J., Cucchiaro, S.J. 1981. Productivity measurement and the bottom line. National Productivity Review, 1(1), 87-99. https://doi.org/10.1002/npr.4040010111.

Md-Rus, R., Mohd, K.N.T., Latif, R.A., Alassan, Z.N. 2013. Ownership Structure and Financial Distress. Journal of Advanced Management Science, Vol, 1(4).

Oz, I.O., Yelkenci, T. 2017. A theoretical approach to financial distress prediction modeling. Managerial Finance, 43(2), 212-230.

Ross, S.A., Westerfield, R.W., Jaffe, J. 2002. Corporate Finance, $6^{\text {th }}$ Edition.

Sahamok.com. 2015. Doid (PT Delta Dunia Makmur Tbk) rugi bersih tahun berturut-turut. Pukul 18.58.

Salehi, M., Moradi, M., Paiydarmanesh, N. 2017. The effect of corporate governance and audit quality on disclosure quality: Evidence from Tehran stock exchange. Periodica Polytechnica Social and Management Sciences, 25(1), 32-48. https://doi.org/10.3311/PPso.8354.

Shahwan. 2017. Corporate Governance. The international journal of business in society, Universidad Icesi, 8(11), 430-439. https://doi.org/10.1590/S004296862002000400009.

Theodossiou, P., Kahya, E., Saidi, R., Philippatos, G. 1996. Financial distress and corporate acquisitions: Further empirical evidence. Journal of Business Finance \& Accounting, 23(5-6), 699-719.

Thim, C.K., Choong, Y.V., Fie, Y.G., Har, L.W. 2014. Assessing Financial Performance of Malaysian Islamic and Conventional Commercial Banks Using Financial Ratios. Journal of Modern Accounting and Auditing, 10(4).

Zmijewski. 1984. Discussion of Methodological Issues Related to the Estimation of Financial Distress Prediction Models. Journal of Accounting Research, 22, 83. https://doi.org/10.2307/2490860. 